Jaworek M., Kuzel M. (2015). Transnational Corporations in the World Economy: Formation, Development and Present Position. Copernican Journal of Finance \& Accounting, 4(1), 55-70. http:// dx.doi.org/10.12775/CJFA.2015.004

\author{
Makgorzata Jaworek* \\ Nicolaus Copernicus University \\ Marcin Kuzel** \\ Nicolaus Copernicus University
}

\title{
TRANSNATIONAL CORPORATIONS IN THE WORLD ECONOMY: FORMATION, DEVELOPMENT AND PRESENT POSITION
}

Keywords: transnational corporations (TNCs), multinational firms, international business, foreign direct investment (FDI), global economy.

\section{J E L Classification: F21, F23.}

Abstract: The following article attempts to answer the question about the role transnational corporations (TNCs) play in the modern world. The issues discussed in this article have been presented in two main parts. The first part focuses on the world's largest TNCs according to the following criteria: the value of the revenues, market capitalization and foreign assets. The discussion in the second part focuses on defining the role that transnational corporations play in the world economy. A number of different characteristics reflecting the economic potential of TNCs have been used in this article such as: asset value, employment rate, sales volume and research and development po-

Date of submission: December 10, 2014; date of acceptance: February 13, 2015.

* Contact information: Malgorzata.Jaworek@umk.pl, Department of Investment and Real Estate, Faculty of Economic Sciences and Management, Nicolaus Copernicus University, Gagarina 13a, 87-100 Toruń, Poland, phone: +4856 6114633

** Contact information: Marcin.Kuzel@umk.pl, Department of Investment and Real Estate, Faculty of Economic Sciences and Management, Nicolaus Copernicus University, Gagarina 13a, 87-100 Toruń, Poland, phone: +4856 6114898.

The authors are grateful to the anonymous referees for their helpful comments and constructive suggestions in strengthening this article. 
tential, which are linked to selected parameters describing the volume of international production. The analysis of TNC development and their present position has been presented from a historical perspective, which made it possible to identify the conditions of as well as the major changes in the process of enterprise internationalisation. The following article highlights the dynamic development of corporations in developing countries and the ever more common phenomenon of state-owned enterprises or enterprises with a state's capital playing a role on the international stage.

Translated by Małgorzata Jaworek and Marcin Kuzel

\section{IIIITRODUCTION}

Embarking on international business ventures is not a new phenomenon. Some researchers suggest that examples of early transnational corporations (TNCs) can already be found in the history of colonial expansion of the ancient Phoenicians and Romans (Dunning 1993, 96; Moore, Lewis 2000, 17-42), and other ancient civilizations before them (Moore, Lewis 2009). Others look for predecessors of modern transnational corporations in the Middle Ages (Dunning, Lundan 2008, 146-148) and the Renaissance period, linking the colonial conquests to the development of famous British and Dutch trading companies (Carlos, Nicholas 1988, 398-419; Robins 2012a; Robins 2012b, 12-26). It was not, however, until the Industrial Revolution of the late 18th and early 19th century that new opportunities in terms of the organization of production processes emerged and changes in the existing patterns of production took place, which led to the emergence of economic organizations resembling modern enterprises. It was mainly because of the above changes that the emergence of modern corporations, sharing a number of characteristics with the TNCs operating today, is usually believed to have originated in the second half, or more specifically, in the last three decades of the 19th century (Dunning 1993, 99; Castro 2000, 7; Wilkins 2001, 4; Dunning, Lundan 2008, 154-175).

The dynamic growth of international production, however, falls predominantly in the 20th century, at the beginning of which, especially in the United States, a corporate economy model emerged, based on large enterprises no longer managed by their owners but by hired qualified professionals (Langlois $2007,1)$. At that time, basic legal and ownership forms (public limited companies) were established and improved on as well as organisational solutions proposed (divisional structures), which prepared corporations from highly developed countries for the global conquest (Zorska 2007,84). The conquest became possible only after the war and intensified in the 1960s and 1970s, after which 
the corporations acquired a nickname cosmocorps. It was then recognized that the largest corporations can control or even dominate many business areas as well as perform roles previously reserved for state structures (Calliess 2011, 601-615; Irogbe 2013, 223). At this time, mainly thanks to S. Hymer and Ch.P. Kindleberger, there was also a wider interest in explaining the nature of multinational corporation activity using theoretical concepts (such as the theory of ownership-specific advantages). It was R. Vernon who made the first ever attempt at estimating the number of corporations, identifying 396 parent companies and their 28,318 foreign affiliates (Cox 1997, 9-46).

In 1974, the United Nations set up a special program for the monitoring of international business activity and the flow of foreign direct investment (FDI), which until 1992 was carried out by the United Nations Centre on Transnational Corporations. It is this organization that introduced the term "transnational corporation" into the international nomenclature, which along with the traditional term "multinational corporation" has become a widely used term for enterprises engaging in foreign direct investment and holding or controlling production or services companies operating in more than one country (Dunning 1993, 3, 11; Zorska 2007, 10).

Rapid technological progress, liberalization of trade, capital flows and the global development of capital markets as well as the processes associated with privatisation, deregulation and de-monopolisation (Thomsen 2000,3) brought a spectacular increase in business activity as well as the number of transnational corporations in the 1980s and 1990s. In 1982, the total global value of FDI amounted to $\$ 579$ billion (UNCTAD 2009, 18). In 1990, the volume of this type of investment reached $\$ 1,786$ billion, while the number of corporations was estimated at about 30,000 and the number of TNC foreign affiliates at 150,000 (Dunning ed. 1993, vii). The years that followed saw further dynamic growth of TNC international expansion (table 1).

Table 1. Outward FDI stocks and the numbers of TNCs, 1995-2010 (\$ Millions)

\begin{tabular}{|l|c|c|c|c|}
\hline \hline \multicolumn{1}{|c|}{ Item } & $\mathbf{1 9 9 5}$ & $\mathbf{2 0 0 0}$ & $\mathbf{2 0 0 5}$ & $\mathbf{2 0 1 0}$ \\
\hline \hline Outward FDI stocks & $3,769,042$ & $8,008,434$ & $12,563,770$ & $21,288,584$ \\
\hline Number of parent corporations & 38,541 & 63,459 & 69,727 & 103,786 \\
\hline Number of foreign affiliates & 251,450 & 689,520 & 690,391 & 892,114 \\
\hline
\end{tabular}

S o u r c e : compiled by the authors on the basis of: UNCTADStat, http://unctadstat.unctad.org (accessed: 15.11.2014); UNCTAD (2000), World Investment Report 2000, Cross-border Mergers 
and Acquisitions, United Nations, New York and Geneva, 11-13 UNCTAD (2005), World Investment Report 2005, Transnational Corporations and the Internationalization of R\&D, United Nations, New York and Geneva, 264-265; UNCTAD (2011), World Investment Report 2011, Non-Equity Modes of International Production and Development, Web Table 34, United Nations, http://unctad. org (accessed: 10.11.2014).

N o t e s : Estimated data; the numbers of parent corporations and foreign affiliates given in 1995, 2000 , and 2005 based on particular economies evidence from the latest available year.

The changes that are shaping today's world economy (technological advances, liberalization of trade and capital flows, etc.), which are enabling TNCs to grow, have made it possible for entirely new corporations to emerge, for which large scale operations and substantial capital resources were no longer a prerequisite for the internationalization of their business activity. More and more small and medium-sized enterprises were transforming into transnational corporations of which international new ventures have become the most telling phenomenon (Aggarwal, Berrill, Hutson, Kearney 2011, 557-577). It was not simply the scale and the scope of their business activity that became crucial for determining the specific nature of transnational corporations but, more importantly, their organizational skills providing them with a better configuration of distributed resources and coordination of their processes on a global scale.

Today TNCs are defined as organisations consisting of a parent company and its foreign affiliates (UNCTAD 2002, 291), whose activity permeates national borders (not necessarily very many) and is organized, integrated and coordinated by the headquarters operating in the home country (Zorska 2007, 10).

In 2010, the value of global FDI exceeded $\$ 21,288.5$ billion, the number of transnational corporations was estimated at over 100,000 and the number of TNC foreign affiliates at over 890,000 (table 1). It seems that multinational corporations have become an important, if not central, element of the global economy and their importance seems to continue to grow. This article presents a description of these organisations and attempts to answer the burning question about the role that transnational corporations play in the modern world.

\section{THE RESEARCH METHODOLOGY AND THE COURSE OF THE RESEARCH PROCESS}

Determining the importance of transnational corporations for the world economy is neither easy nor obvious. The majority of authors dealing with the subject of TNCs take their significant role in forming international economic relations for granted, without attempting to specify it any further (e.g. Birkinshaw, Ghoshal, Markides, Stopford, Yip 2003; Ietto-Gillies 2005). At the same time, 
there is still a shortage of studies based on factual documentation, statistical data or research findings which could illustrate the real role that TNCs play in the world economy. Some of the few publications in that field include work by such authors as J. Kleinert (2004), A. Zorska (2007), J.H. Dunning and S.M. Lundan (2008), M. Gasz (2012) or W. Karaszewski (2004; 2013). This article aims to at least partially bridge this gap.

The aim of this paper is to present the world's largest transnational corporations and to indicate the role that TNCs play in the global economy. That is why the paper has been divided into two main parts. The first part will demonstrate a leading group of TNC-type organisations, which have been classified in terms of their:

- revenues, which made it possible to define the largest "trading powers";

- market capitalization value, which made it possible to define the "capital powers";

- TNC foreign assets, which made it possible to define a group of companies with most capital invested outside their home country.

To determine a leading TNC group, periodical rankings have been used published by organizations such as: United Nations Conference on Trade and Development (UNCTAD), PricewaterhouseCoopers (PwC), Strategy\&, as well as lists of largest companies presented in the Fortune journal.

The second part of this article is an attempt to define the role that TNCs play in the world economy. Unfortunately, there are no synthetic measures which could be used to define that role. Therefore, in order to assess the role transnational corporations play in the world economy, data showing the economic potential of TNCs has been used, in particular the description of their foreign affiliates business activity, including the value of their assets, revenue, exports, the number of employees and value added. The article also presents the TNC affiliate value of revenue and their value of exports against world exports as well as compares the affiliate added value to global GDP. It also points out the research and development potential of selected TNCs, as measured by the volume of research and development (R\&D) expenditure.

The choice of economic parameters presented below and the related parameter formulas proposed by the authors are based on preliminary research of academic publications included in the canon of the literature on the subject as well as available rankings of transnational corporations and the authors' own conclusions. The methods of comparative analysis, the diachronic analysis and the method of induction have been used in this study. 


\section{THE WORLD'S LARGEST TRANSNATIONAL CORPORATIONS}

Since 1994 the Fortune magazine has presented an annual classification of enterprises according to their value of revenue ranking 500 corporations - the biggest global trading powers. In 2013, these 500 largest companies had a total revenue of $\$ 31.1$ trillion. Their profit had increased by $27 \%$, reaching nearly $\$ 2$ trillion. There were 95 Chinese and 128 US corporations on that list, making the United States the world leader (Fortune Global 500 2014). The leader on the list was a United States corporation - Wal-Mart Stores - with the total revenue of $\$ 476,294$ million and the profit of $\$ 16,022$ million. The top ten also included another US company, one corporation from Japan, four from Western Europe and three from China (table 2).

Table 2. The world's top 10 TNCs, ranked by revenues, 2013 (\$ Millions)

\begin{tabular}{|l|l|c|c|}
\hline \multicolumn{1}{|c|}{ Corporation } & \multicolumn{1}{|c|}{ Home economy } & Revenues & Profits \\
\hline \hline Wal-Mart Stores & United States & 476,294 & 16,022 \\
\hline Royal Dutch Shell & $\begin{array}{l}\text { United Kingdom / Nether- } \\
\text { lands }\end{array}$ & 459,599 & 16,371 \\
\hline Sinopec Group & China & 457,201 & 8,932 \\
\hline China National Petroleum & China & 432,008 & 18,505 \\
\hline Exxon Mobil & United States & 407,666 & 32,580 \\
\hline BP & United Kingdom & 396,217 & 23,451 \\
\hline State Grid & China & 333,387 & 7,982 \\
\hline Volkswagen & Germany & 261,539 & 12,072 \\
\hline Toyota Motor & Japan & 256,454 & 18,198 \\
\hline Glencore & Switzerland & 232,694 & $-7,402$ \\
\hline \hline
\end{tabular}

S o u r c e : Fortune Global 500 (2014), http://fortune.com/global500 (accessed: 27.10.2014).

This TNC classification according to their market capitalization value is prepared by $\mathrm{PwC}$. It includes 100 of the most valuable companies in the world. Market capitalization of all the companies included in the 2014 ranking amounted to $\$ 15,020$ billion ( $\$ 8,403$ billion in 2009), of which only 29 companies had a market value of less than $\$ 100$ billion. The list included 47 TNCs from the United States, 18 from the Euro zone and 8 from China / Hong Kong 
(PwC 2014). A US corporation Apple topped the list with a market capitalization value of $\$ 469$ billion. Among the first 10 TNCs with the largest market value there were as many as eight companies from the United States and two from Switzerland (table 3).

Table 3. The world's top 10 TNCs, ranked by market capitalisation, 2014 (\$ Billions)

\begin{tabular}{|c|c|c|c|c|c|}
\hline \multirow[b]{2}{*}{ Corporation } & \multirow[b]{2}{*}{ Home economy } & \multicolumn{2}{|c|}{31 March 2014} & \multicolumn{2}{|c|}{31 March 2009} \\
\hline & & Rank & $\begin{array}{c}\text { Market } \\
\text { Capitalisation }\end{array}$ & Rank & $\begin{array}{c}\text { Market } \\
\text { Capitalisation }\end{array}$ \\
\hline Apple & United States & 1 & 469 & 33 & 94 \\
\hline Exxon Mobil & United States & 2 & 416 & 1 & 337 \\
\hline Google & United States & 3 & 409 & 22 & 110 \\
\hline Microsoft & United States & 4 & 318 & 6 & 163 \\
\hline Berkshire Hathaway & United States & 5 & 286 & 12 & 134 \\
\hline Roche Holding & Switzerland & 6 & 266 & 18 & 119 \\
\hline Johnson \& Johnson & United States & 7 & 261 & 8 & 145 \\
\hline General Electric & United States & 8 & 256 & 24 & 107 \\
\hline Wells Fargo \& Co. & United States & 9 & 244 & 55 & 60 \\
\hline Nestle & Switzerland & 10 & 244 & 15 & 129 \\
\hline
\end{tabular}

S o u r c e : PwC (2014), Global Top 100 Companies by Market Capitalisation, http://www.pwc.com (accessed: 27.10.2014).

Classification of transnational corporations with the largest foreign assets includes the most significant and specific attribute of TNC business activity, which, according to the researchers, is the capital invested outside their home country. The list of the world's 100 largest companies with the largest assets abroad is prepared by UNCTAD. As of the end of 2013, most TNCs were from the United States (24). There were a total of 72 corporations from the five Triad countries (United States, Japan, Germany, France, United Kingdom). The total value of foreign assets of the 100 largest non-financial TNCs amounted to $\$ 8,103,862$ million (UNCTAD 2014a). The General Electric Corporation from the United States topped the list with $\$ 331,160$ million. An average rate of transnationalisation of the 100 TNCs included in the 2013 UNCTAD ranking was $64.5 \%$, with Nestle from Switzerland having the highest rate at $97.1 \%$ and ranking 15 th on the list. 
It is important to note the ever more significant role of transnational corporations from developing countries. Among the top 100 world's largest corporations at the end of 2013 there were as many as 10 TNCs from developing countries. A state-owned corporation from Hong Kong - Hutchison Whampoa Limited - ranked the highest among these enterprises at 26th place (UNCTAD 2014a).

Table 4. The world's top 10 non-financial TNCs, ranked by foreign assets, 2013 (\$ Millions)

\begin{tabular}{|c|c|c|c|c|}
\hline \multirow{2}{*}{ Corporation } & \multirow{2}{*}{ Home economy } & \multicolumn{2}{|c|}{ Assets } & \multirow{2}{*}{ TNla (percent) } \\
\hline & & Foreign & Total & \\
\hline General Electric & United States & 331,160 & 656,560 & 48.8 \\
\hline Royal Dutch Shell & $\begin{array}{l}\text { United Kingdom / } \\
\text { Netherlands }\end{array}$ & 301,898 & 357,512 & 72.8 \\
\hline Toyota Motor & Japan & 274,380 & 403,088 & 58.6 \\
\hline Exxon Mobil & United States & 231,033 & 346,808 & 62.6 \\
\hline Total SA & France & 226,717 & 238,870 & 79.5 \\
\hline $\mathrm{BP}$ & United Kingdom & 202,899 & 305,690 & 69.7 \\
\hline Vodafone Group & United Kingdom & 182,837 & 202,763 & 88.9 \\
\hline Volkswagen & Germany & 176,656 & 446,555 & 58.6 \\
\hline Chevron Corp. & United States & 175,736 & 253,753 & 59.3 \\
\hline Eni SpA & Italy & 141,021 & 190,125 & 71.2 \\
\hline
\end{tabular}

S o u r c e: UNCTAD (2014a), World Investment Report 2014, Investing in the SDGs: An Action Plan, Annex Table 28, United Nations, http://unctad.org (accessed: 27.10.2014).

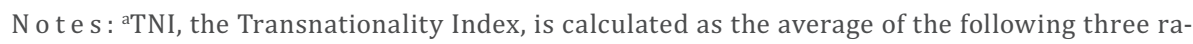
tios: foreign assets to total assets, foreign sales to total sales and foreign employment to total employment.

While presenting the world's largest TNCs, it is worth mentioning the stateowned TNCs (SO-TNCs). Even though they form a small fraction of transnational corporations, SO-TNCs have a significant number of foreign branches and assets. According to UNCTAD, there are at least 550 SO-TNCs operating globally and their total foreign assets are estimated at over $\$ 2$ trillion. These enterprises originate in both developed and developing countries (UNCTAD 2014b, 21). A French corporation GDF Suez topped the list of the largest SO-TNCs with the value of foreign assets at $\$ 175$ billion (table 5). 
Table 5. The world's top 10 non-financial state-owned TNCs, ranked by foreign assets, 2012 (\$ Billions)

\begin{tabular}{|c|c|c|c|c|c|}
\hline \multirow{2}{*}{ Corporation } & \multirow{2}{*}{ Home economy } & \multirow{2}{*}{$\begin{array}{l}\text { State share } \\
\text { (percent) }\end{array}$} & \multicolumn{2}{|c|}{ Assets } & \multirow{2}{*}{ TNIa } \\
\hline & & & Foreign & Total & \\
\hline GDF Suez & France & 36 & 175 & 272 & 0.59 \\
\hline Volkswagen & Germany & 20 & 158 & 409 & 0.58 \\
\hline Eni SpA & Italy & 26 & 133 & 185 & 0.63 \\
\hline Enel SpA & Italy & 31 & 132 & 227 & 0.57 \\
\hline EDF SA & France & 84 & 103 & 331 & 0.31 \\
\hline Deutsche Telekom AG & Germany & 32 & 96 & 143 & 0.58 \\
\hline CITIC Group & China & 100 & 72 & 515 & 0.18 \\
\hline Statoil ASA & Norway & 67 & 71 & 141 & 0.29 \\
\hline General Motors & United States & 16 & 70 & 149 & 0.47 \\
\hline Vattenfall $A B$ & Sweden & 100 & 54 & 81 & 0.72 \\
\hline
\end{tabular}

S o u r c e : UNCTAD (2014b), World Investment Report 2014, Investing in the SDGs: An Action Plan, United Nations, New York and Geneva, 21.

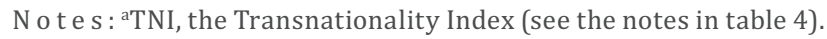

\section{THE ROLE OF TRANSNATIONAL CORPORATIONS IN THE WORLD ECONOMY}

Determining the role TNCs play in the world economy requires taking many aspects of their functioning into account. There is no single synthetic indicator that would directly reflect the role TNCs play in the world economy. Numerous characteristics outlined below prove the importance of the organisations featuring in this article.

TNCs have greater economic potential than many national economies around the globe and they take strategic decisions and actions, which are to a certain extent independent of the interests of the countries in which they operate. To fully understand the economic power of these enterprises in today's global economy they are often compared to national economies. Such a comparison was made in 2000 (Anderson, Cavanagh 2000, 9), and then repeated by UNCTAD in 2002 after making adjustments for certain methodical inaccuracies. The list of the world's 100 largest economic powers drafted at that time included 29 corporations and 71 countries (table 6). 
Table 6. The world's top TNCs vs. economies in 2000 (\$ Billions)

\begin{tabular}{|c|c|c|c|c|c|}
\hline Rank & Corporation / Economy & Value Added/GDPa & Rank & Corporation / Economy & Value Added/ GDPa \\
\hline 1 & United States & 9.810 & 46 & Pakistan & 62 \\
\hline 2 & Japan & 4.765 & 47 & General Motors & $56 b$ \\
\hline 3 & Germany & 1.866 & $\ldots$ & $\ldots$ & $\ldots$ \\
\hline 4 & United Kingdom & 1.427 & 54 & Hungary & 46 \\
\hline 5 & France & 1.294 & 55 & Ford Motor & 44 \\
\hline 6 & China & 1.080 & 56 & DaimlerChrysler & 42 \\
\hline 7 & Italy & 1.074 & 57 & Nigeria & 41 \\
\hline 8 & Canada & 701 & 58 & General Electric & $39 b$ \\
\hline$\ldots$ & $\ldots$ & $\ldots$ & 59 & Toyota Motor & $38 \mathrm{~b}$ \\
\hline 28 & Poland & 158 & 60 & Kuwait & 38 \\
\hline$\ldots$ & $\ldots$ & $\ldots$ & 61 & Romania & 37 \\
\hline 42 & Columbia & 81 & 62 & Royal Dutch Shell & 36 \\
\hline 43 & Philippines & 75 & 63 & Morocco & 33 \\
\hline 44 & Chile & 71 & 64 & Ukraine & 32 \\
\hline 45 & Exxon Mobil & $63 b$ & 65 & Siemens & 32 \\
\hline
\end{tabular}

S o u r c : UNCTAD (2002), World Investment Report 2002, Transnational Corporations and Export Competitiveness, United Nations, New York and Geneva, 90.

N o te s: a GDP for countries and value added for TNCs. Value added is defined as the sum of salaries, pre-tax profits, depreciation and amortisation; ${ }^{b}$ Value added is estimated by applying the 30 percent share of value added in the total sales, 2000, of 66 manufacturers for which the data was available.

The importance of transnational corporations in the world economy can be proven by the characteristics relating to the value of TNC foreign affiliate assets, employment rate, value added and export volumes, which grew steadily in the period 1982-2013. A 47-fold increase has been observed with respect to the asset value. The role of TNCs in the world economy can also be seen by looking at the indicators relating to the foreign affiliates' share of sales and export in the world exports of products and services. At the end of 2013, foreign affiliates' export accounted for over $30 \%$ of world exports and their sales were 1.5 times higher than the global exports (table 7). J. Kleinert (2004, 2628) also indicates that the role TNCs play in forming international trade flows 
is even bigger. He estimates that TNCs participate in around $80 \%$ of all international trade, while approximately a third takes place within TNCs themselves (intra-firm trade), of which over half are indirect goods (materials, parts, components).

Table 7. Selected indicators of international production, 1982-2013 (\$ Billions)

\begin{tabular}{|l|c|c|c|c|c|}
\hline \hline \multicolumn{1}{|c|}{ Item } & 1982 & 1990 & 2000 & $\mathbf{2 0 1 0}$ & $\mathbf{2 0 1 3}$ \\
\hline \hline Total assets of foreign affiliates & 2,036 & 3,893 & 21,102 & 78,631 & 96,625 \\
\hline $\begin{array}{l}\text { Employment by foreign affiliates } \\
\text { (thousands) }\end{array}$ & 19,864 & 20,625 & 45,587 & 63,043 & 70,726 \\
\hline $\begin{array}{l}\text { Value added (product) of foreign } \\
\text { affiliates }\end{array}$ & 623 & 881 & 3,167 & 5,735 & 7,492 \\
\hline Exports of foreign affiliates & 635 & 1,498 & 3,572 & 7,436 & 7,721 \\
\hline $\begin{array}{l}\text { Sales of foreign affiliates } \\
\text { Value added (product) of foreign } \\
\text { affiliates } \\
\text { to global GDP ratio }\end{array}$ & 0.05 & 0.04 & 0.10 & 0.09 & 0.10 \\
\hline $\begin{array}{l}\text { Exports of foreign affiliates to global } \\
\text { exports of goods and services ratio }\end{array}$ & 0.27 & 0.36 & 0.51 & 0.39 & 0.33 \\
\hline $\begin{array}{l}\text { Sales of foreign affiliates to global } \\
\text { exports of goods and services ratio }\end{array}$ & 1.06 & 1.15 & 2.23 & 1.19 & 1.49 \\
\hline \hline
\end{tabular}

S o u r c e : compiled by the authors on the basis of: UNCTAD (2001), World Investment Report 2001, Promoting Linkages, United Nations, New York and Geneva, 10; UNCTAD (2009), World Investment Report 2009, Transnational Corporations, Agricultural Production and Development, United Nations, New York and Geneva, 18; UNCTAD (2013), World Investment Report 2013, Global Value Chains: Investment and Trade for Development, United Nations, New York and Geneva, xvi; UNCTAD (2014b), World Investment Report 2014, Investing in the SDGs: An Action Plan, United Nations, New York and Geneva, xviii.

A crucial aspect of the role TNCs play in the world economy is their participation in research and development work around the globe. In 2002, 700 leading corporations allocated approximately $\$ 310$ billion to R\&D activity, which was equivalent to $46 \%$ of the total global R\&D expenditure and as much as $69 \%$ of the funds spent on R\&D by the whole business sector (OECD 2002, 103). It should also be noted that in some countries the TNCs' share in the financing of R\&D can be decisive and may be as high as over 50\% (Lall 2002, 54; UNCTAD 2005, 292-293). According to the 2014 ranking, five companies from the United States, two from Switzerland and one from Japan, South Korea and Germany were among the top 10 TNCs in terms of R\&D expenditure. Volkswagen from 
Germany spent most on R\&D. Their research and development expenditure of $\$ 13.5$ billion accounted for $4.6 \%$ of the corporation's total sales (table 8). The highest R\&D expenditure in relation to their sales volume was achieved by Swiss Roche $-19.8 \%$, followed by a US corporation Intel $-18.9 \%$ (Strategy\& 2014).

Table 8. The world's top 10 R\&D spenders, 2014 (\$ Billions)

\begin{tabular}{|l|l|l|c|}
\hline \hline \multicolumn{1}{|c|}{ Corporation } & \multicolumn{1}{|c|}{ Home economy } & \multicolumn{1}{c|}{ Industry } & R\&D Spend \\
\hline \hline Volkswagen & Germany & Automotive & 13.5 \\
\hline Samsung & South Korea & Computing and electronics & 13.4 \\
\hline Intel & United States & Computing and electronics & 10.6 \\
\hline Microsoft & United States & Software and Internet & 10.4 \\
\hline Roche & Switzerland & Healthcare & 10.0 \\
\hline Novartis & Switzerland & Healthcare & 9.9 \\
\hline Toyota & Japan & Automotive & 9.1 \\
\hline Johnson \& Johnson & United States & Healthcare & 8.2 \\
\hline Google & United States & Software and Internet & 8.0 \\
\hline Merck & United States & Healthcare & 7.5 \\
\hline \hline
\end{tabular}

S o u r c e : Strategy\& (2014), The Global Innovation 1000 Study: The Top Innovators and Spenders, http://www.strategyand.pwc.com (accessed: 10.11.2014).

Substantial spending on research and development (the most active corporations have larger R\&D budgets than medium-sized countries - UNCTAD 2005,120 ), the ability to implement cost-intensive innovation projects and generate innovative organisational solutions form the basis for the global competitiveness of TNCs. The result is impressive profits (table 2), which allow even greater accumulation of capital and further intensive international expansion through the implementation of large scale and impressive range investment projects (Karaszewski 2013, 227-240). This phenomenon results in a significant concentration of resources at the disposal of a limited number of companies, which leads to continuously growing disparities in the use of the world's knowledge, skills and technology (Karaszewski 2004, 400-402). 


\section{FINAL REMARKS AND CONCLUSIONS}

Although researchers cannot fully agree on the origins of the structures that gave rise to the emergence of transnational corporations, it is clear that the dynamic growth of these companies dates back to the second half of the twentieth century, and in particular to its last two decades and the first decade of the 21st century. Between 1995 and 2010 the number of TNCs increased more than 2.5-fold, and the number of their foreign affiliates - over 3.5-fold (table 1). In 2013, TNC foreign affiliates employed a total of 70,726,000 employees, the value of their assets was estimated at $\$ 96,625$ billion and the scale of their business activity accounted for $10 \%$ of global GDP. TNC affiliates' sales at that time amounted to $\$ 34,508$ billion and were nearly 1.5 times higher than total world exports. The value of their export sales stood at $\$ 7,721$ billion and accounted for $30 \%$ of total world exports (table 7 ).

The economic potential of transnational corporations can be proven by the leaders' performance in the various categories analyzed in this study. In 2013 alone, the world's 500 largest trading powers among TNCs generated a total revenue of $\$ 31.1$ trillion, and their profits were estimated at $\$ 2$ trillion (Fortune Global 500 in 2014). Market capitalization of the 100 most valuable TNCs amounted to as much as $\$ 15,020$ billion as of March 2014 (PwC 2014). Their considerable investment outside their home countries can be seen by looking at the value of their foreign assets, which in the case of the world's 100 largest non-financial TNCs totalled $\$ 8,103,862$ million in 2013. An average value for the TNI index for this group of businesses at that time stood at $64.5 \%$ (UNCTAD 2014a).

All TNC characteristics presented in this paper confirm the great economic power of these companies. It is so impressive that they are often compared to national economies. The list of the world's 100 biggest economic powers drafted in 2002 by UNCTAD included 29 corporations (UNCTAD 2002). TNCs also play an important role in research and development work. R\&D spending among the most active corporations can be larger than that of mediumsized countries. In 2014, the top ten R\&D spenders allocated $\$ 100.3$ billion to research and development projects (Strategy\& 2014).

The rankings presented here highlight the importance of the world's largest corporations, which stand out in terms of trade, capital, investment and research. It should be noted, however, that although these enterprises utilize considerable resources, and hence also attract the attention of the world, they 
reflect achievements of a relatively small number of organisations which belong to a wide and diverse category of TNCs. It is a small fraction of a community of over 100,000 companies. One should keep in mind the growing number of small and medium-sized enterprises, which now form a sizeable part of transnational corporations and which to a large extent shape the landscape of the modern world and play a significant role in the world economy even if they do not top the rankings presented in this paper. There has recently been a rapid increase in the quantity and strength of corporate capital from developing countries, in particular from countries in South Asia, East Asia and South-East Asia, including China and Hong Kong, South Korea, Taiwan and India. More and more state enterprises or enterprises with state capital can also be seen in the international space.

If we consider the tendency outlined above, it can be concluded that the changes that have been observed in the processes of formation and international expansion of TNCs suggest that this historically rooted process of international business growth, shaped mainly by large private companies from developed countries, is now increasingly complemented and enriched by the dynamic growth of corporations in developing countries. These are often smaller than the world's leading corporations, though not necessarily small in themselves, but with similarly high international, if not global, aspirations. It is to be expected that the pursuit of these aspirations will probably be one of the most exciting symptoms of the changes in international business growth in the near future.

\section{REFERENCES}

Aggarwal R., Berrill J., Hutson E., Kearney C. (2011). What is a Multinational Company? Classifying the Degree of Firm-Level Multinationality. International Business Review, 5(20), 557-577. http://dx.doi.org/10.2139/ssrn.900522.

Anderson S., Cavanagh J. (2000), The Rise of Corporate Global Power, Institute for Policy Studies, Washington, http://s3.amazonaws.com/corpwatch.org/downloads/ top200.pdf (accessed: 20.11.2014).

Birkinshaw J., Ghoshal S., Markides C., Stopford J., Yip G. (2003), The Future of the Multinational Company, John Wiley \& Sons, Chichester.

Calliess G.P. (2011). Transnational Corporations Revisited. Indiana Journal of Global Legal Studies, 2(18), 601-615.

Carlos A.M., Nicholas S. (1988). "Giants of an Earlier Capitalism”: The Chartered Trading Companies as Modern Multinationals. The Business History Review, 3(62), 398-419. http://dx.doi.org/10.2307/3115542. 
Castro F.B. (2000), Foreign Direct Investment in the European Periphery. The Competitiveness of Portugal, PhD Thesis, University of Leeds, http://etheses.whiterose. ac.uk/2612 (accessed: 14.11.2014).

Cox H. (1997), The Evolution of International Business Enterprise, 9-46 [in:] Global Business Strategy, R. John (ed.), International Thomson, London, https://eprints.worc. ac.uk/250 (accessed: 14.11.2014).

Dunning J.H. (1993), Multinational Enterprise and the Global Economy, Addison-Wesley, Wokingham.

Dunning J.H. (ed.) (1993), The Theory of Transnational Corporations, United Nations Library on Transnational Corporations Vol. 1, Routledge, London and New York.

Dunning J.H., Lundan S.M. (2008), Multinational Enterprises and the Global Economy, Edward Elgar Publishing, Cheltenham-Northampton.

Fortune Global 500 (2014), http://fortune.com/global500 (accessed: 27.10.2014).

Gasz M. (2012). Znaczenie korporacji transnarodowych w gospodarce światowej. Ekonomia i Prawo, 4(11), 29-45. http://dx.doi.org/10.12775/EiP.2012.031.

Ietto-Gillies G. (2005), Transnational Corporations and International Production: Concepts, Theories and Effects, Edward Elgar Publishing, Cheltenham-Northampton.

Irogbe K. (2013). Global Political Economy and the Power of Multinational Corporations. Journal of Third World Studies, 2(XXX), 223-247.

Karaszewski W. (2004), Największe korporacje transnarodowe świata i ich wpływ na wzrost gospodarczy, 373-404 [in:] Czynniki wzrostu gospodarczego, M. Haffer, W. Karaszewski (eds.), Wydawnictwo Uniwersytetu Mikołaja Kopernika, Toruń.

Karaszewski W. (2013), Najwięksi inwestorzy świata, 227-240 [in:] Inwestycje i nieruchomości we współczesnej gospodarce, K. Marcinek (ed.), Wydawnictwo Uniwersytetu Ekonomicznego w Katowicach, Katowice.

Kleinert J. (2004), The Role of Multinational Enterprises in Globalization, Springer-Verlag, Berlin and Heidelberg and New York.

Lall S. (2002). Linking FDI and Technology Development for Capacity Building and Strategic Competitiveness. Transnational Corporations, 3(11), 39-88.

Langlois R.N. (2007), The Dynamics of Industrial Capitalism. Schumpeter, Chandler, and the New Economy, Routledge, London and New York. http://dx.doi. org/10.4324/9780203963630.

Moore K.J., Lewis D.Ch. (2000). Multinational Enterprise in Ancient Phoenicia. Business History, 2(42), 17-42. http://dx.doi.org/10.1080/00076790000000219.

Moore K.J., Lewis D.Ch. (2009), The Origins of Globalization, Routledge, New York.

OECD (2002), Direct Investment for Development. Maximising Benefits, Minimising Costs, Committee for International Investment and Multinational Enterprise (CIME).

PwC (2014), Global Top 100 Companies by Market Capitalisation, http://www.pwc. com/gx/en/audit-services/capital-market/publications/assets/document/pwc-global-top-100-march-update.pdf (accessed: 27.10.2014).

Robins N. (2012a), Corporation That Changed the World. How the East India Company Shaped the Modern Multinational, Pluto Press, London. 
Robins N. (2012b). Corporation That Changed the World. How the East India Company Shaped the Modern Multinational, Asian Affairs 1(XLIII), 12-26. http://dx.doi.org/1 0.1080/03068374.2012.642512.

Strategy\& (2014), The Global Innovation 1000 Study: The Top Innovators and Spenders, http://www.strategyand.pwc.com/global/home/what-we-think/global-innovation-1000/top-innovators-spenders\#/tab-2014 (accessed: 10.11.2014).

Thomsen S. (2000), Investment Patterns in a Longer-Term Perspective, OECD Working Papers on International Investment, 2000/02, http://www.oecd.org/daf/inv/investment-policy/WP-2000_2.pdf. http://dx.doi.org/10.1787/150177306672.

UNCTADStat, http://unctadstat.unctad.org/wds/TableViewer/tableView.aspx (accessed: 15.11.2014).

UNCTAD (2000), World Investment Report 2000, Cross-border Mergers and Acquisitions, United Nations, New York and Geneva.

UNCTAD (2001), World Investment Report 2001, Promoting Linkages, United Nations, New York and Geneva.

UNCTAD (2002), World Investment Report 2002, Transnational Corporations and Export Competitiveness, United Nations, New York and Geneva.

UNCTAD (2005), World Investment Report 2005, Transnational Corporations and the Internationalization of R\&D, United Nations, New York and Geneva.

UNCTAD (2009), World Investment Report 2009, Transnational Corporations, Agricultural Production and Development, United Nations, New York and Geneva.

UNCTAD (2011), World Investment Report 2011, Non-Equity Modes of International Production and Development, Web Table 34, United Nations, http://unctad.org/sections/dite_dir/docs/WIR11_web\%20tab\%2034.pdf (accessed: 10.11.2014).

UNCTAD (2013), World Investment Report 2013, Global Value Chains: Investment and Trade for Development, United Nations, New York and Geneva.

UNCTAD (2014a), World Investment Report 2014, Investing in the SDGs: An Action Plan, Annex Table 28, United Nations, http://unctad.org/en/Pages/DIAE/World\%20Investment\%20Report/Annex-Tables.aspx (accessed: 27.10.2014).

UNCTAD (2014b), World Investment Report 2014, Investing in the SDGs: An Action Plan, United Nations, New York and Geneva.

Wilkins M. (2001), The History of Multinational Enterprise, 3-35 [in:] The Oxford Handbook of International Business, A.M. Rugman, T.L. Brewer (eds.), Oxford University Press. http://dx.doi.org/10.1093/0199241821.003.0001.

Zorska A. (2007), Korporacje transnarodowe. Przemiany, oddziaływania, wyzwania, Polskie Wydawnictwo Ekonomiczne, Warszawa. 